This is an electronic reprint of the original article. This reprint may differ from the original in pagination and typographic detail.

Author(s): Strömmer, Maiju

Title: $\quad$ Affordances and constraints : Second language learning in cleaning work

Year: $\quad 2016$

Version:

Please cite the original version:

Strömmer, M. (2016). Affordances and constraints : Second language learning in cleaning work. Multilingua : Journal of Cross-Cultural and Interlanguage Communication, 35(6), 697-721. https://doi.org/10.1515/multi-2014-0113

All material supplied via JYX is protected by copyright and other intellectual property rights, and duplication or sale of all or part of any of the repository collections is not permitted, except that material may be duplicated by you for your research use or educational purposes in electronic or print form. You must obtain permission for any other use. Electronic or print copies may not be offered, whether for sale or otherwise to anyone who is not an authorised user. 
Maiju Strömmer*

\section{Affordances and constraints: Second language learning in cleaning work}

DOI 10.1515/multi-2014-0113

Abstract: This paper examines opportunities for language learning in a cleaning job, which is a typical entry-level job for immigrants. An ethnographic case study approach is taken to investigate examples of the conditions that allow or prevent language learning for the focal participant, a sub-Saharan man who works as a cleaner in Finland. This case illustrates on a micro-scale the impact of the new economy on a worker in a company that has outsourced its cleaning services. Theoretically and methodologically, the study applies van Lier's (2004) ecological approach to language learning and Scollon and Scollon's (2004) nexus analysis. The analysis of interaction order shows that within outsourced cleaning services, the cleaner is isolated from the work community around him and communication between him and clients is relayed through intermediaries. Consequently, only occasional opportunities arise for interaction in L2 in the workplace. Examples of work situations that offer affordances for linguistic action are analysed in depth to find out how work-related language learning could be supported. However, the pedagogical value of such affordances might be rather low, and hence, as it often offers very limited opportunities for developing second language skills, cleaning may be a dead-end job.

Keywords: language in the workplace, migration, second language learning, ethnography, nexus analysis, ecological approach

\section{Introduction}

This study investigates second language learning in a cleaning job, which is a typical entry-level job for immigrants. These insecure, low-paid jobs are often the only option open to newly arrived immigrants, whatever their educational background and earlier work experience (Roberts 2010: 217). In Finland, every fifth office cleaner $(8,377$ out of 43,054 in 2011) is of foreign origin (Official Statistics of Finland 2013). Cleaning is in fact the most common work for immigrants, but many of them consider it temporary, while they try to find a

*Corresponding author: Maiju Strömmer, Department of Languages, University of Jyvaskyla, Jyvaskyla, Finland, E-mail: maiju.strommer@jyu.fi 
place in their own field of expertise (Trux 2002). However, Finnish language skills are often required to obtain a position in the broader labour market in Finland, and hence learning the language is a prerequisite for entry into most careers. Little empirical research has been conducted on language learning in the context of cleaning jobs. The opportunities for and constraints on language learning in the cleaning industry are inherently complex and need to be problematized and explored in depth.

To examine the opportunities for language learning, this study takes an ethnographic case study approach and focuses on a sub-Saharan immigrant working as a cleaner in Finland. This case is representative of the new flows of transnational migration within the new economic order that are challenging language practices and institutional policies throughout the world (see Duchêne et al. 2013). In most Finnish institutions, cleaning services have been outsourced and subcontracted. This means that the physical cleaning work typically occurs on the client's rather than the employer's premises (Trux 2002: 185-186). This study investigates how the effects of this quite recent structural change in the cleaning industry operate at the micro level in a workplace that has outsourced its cleaning services. The research questions are: First, what opportunities and constraints are there for the participant to learn Finnish in his cleaning job? Second, how does the participant create and use opportunities to develop his Finnish language skills?

The paper begins with a literature review and presentation of the theoretical background, followed by an outline of the methodology and data. Theoretically, the study draws on the ecological approach to second language learning (van Lier 2004), and nexus analysis (Scollon and Scollon 2004) is applied as an analytical framework. In the spirit of nexus analysis, I zoom in on examples of social actions that afford or inhibit opportunities for learning the Finnish language in cleaning work and analyse their interaction order. I conclude by considering the broader implications of this case study.

\section{Language learning in entry-level jobs}

The workplace is often regarded as a site for language socialization, the process by which newcomers in a community gain language skills, membership, and legitimacy in the group (Duff 2007: 310). Newly arrived migrants experience a double socialization into the workplace, because they need to learn a new language and culture in addition to the practices of the new work environment (Li 2000). So far, workplace-oriented language learning research has mostly focused on discipline-specific discourse practices in professions that require higher education, such as engineering, law, medicine and nursing (Duff 2008: 265; 
Duff et al. 2000; Mertz 2007; Sarangi and Roberts 1999). However, as Angouri (2014: 4) emphasizes, it is relevant to explore also blue collar workers who are not yet fluent in the company's working language. McCall (2003) points out that "language-marginal" jobs like cleaning or factory work allow only little language use because of the noise of machines, the isolated nature of the work, and the physical distance between co-workers. However, these jobs have received little empirical attention. More research is needed to understand the language learning and socialization within the jobs that immigrants can get before they have gained a sufficient level of proficiency in the local language to be considered for higher positions.

Nevertheless, a few ethnographic studies have explored language learning in language-marginal jobs (e.g. Goldstein 1997; Sandwall 2013; Piller and Lising 2014). Piller and Lising (2014) argue that when language proficiency is not a recruitment criterion, as is the case for Philippine temporary meat workers who go to Australia with limited English language proficiency, there are correspondingly only limited opportunities to practice language at work. Similarly, Sandwall (2013) found that the work placements which were part of the basic Swedish language program for adult immigrants in Sweden offered the immigrant interns mostly non-linguistic work tasks; they talked only between 30 seconds and 2 minutes per workday, on average. In that study, cleaning tasks included very little interaction with fellow workers and customers. Furthermore, Goldstein (1997) showed that Portuguese factory workers in Toronto were isolated from English language resources at work.

In general, as Billet (2001) has pointed out, learning at work arises from participation in work activities and direct and indirect support. Learning depends on both the individual and opportunities for learning afforded by the workplace. However, not all workers get the opportunities they need. (Billet 2001: 209-210.) Previous studies (Suni 2010; Virtanen 2013; Partanen 2013) on the development of work-related Finnish language skills have shown that the support received from the work community is essential for migrant employees. Therefore, interaction orders within the surrounding work community are explored in this study.

\section{Ecological approach to language learning}

The theoretical framework of this study is van Lier's (2000, 2004) ecological approach to language, learning, and cognition. It is based on Bakhtin's dialogical philosophy and the psychological work of Vygotsky, who emphasized the social nature of learning. Following these approaches, the focus in second language studies is gradually shifting to meaningful activities and situations that learners 
engage in when using and learning languages (van Lier 2007: 46; Block 2003; Lantolf and Thorne 2006; Atkinson 2011; Dufva et al. 2011). From an ecological perspective, the environment provides a semiotic budget, which provides opportunities for meaningful actions in different situations (van Lier 2000: 252). The emphasis is on the ways in which learners use language and other semiotic systems in order to relate to their physical and social surroundings (van Lier 2007: 47). The ecological approach looks at the entire situation: context and environment, but also movement, process, and action that happen in time and place (van Lier 2004: 10).

Relations between individuals and the social world are referred to as affordances (Gibson 1979; van Lier 2000, 2004). The physical and social surroundings afford many relevancies, which the language learner perceives and interprets and may use for further action, interaction and language learning. The ability to perceive and utilize these affordances is a prerequisite for language learning. Linguistic resources in the environment are learning potentials, but they do not automatically produce learning or become affordances. From all of the opportunities that the environment offers for action, learners select those that are somehow meaningful or useful for the activity in which they are engaged. (van Lier 2004.) Linguistic affordances are linked to nonverbal aspects of meaning making, such as gestures and artifacts, and they make sense only when seen in their interconnectedness (Barab and Roth 2006). Since language is multimodal and perception is multisensory, language learning research needs to acquire a holistic, whole-person, embodied approach (van Lier 2007: 54, 62).

The ecological approach to language learning offers a theoretical vantage point for this study, allowing us to look at the complexity of the relations between individuals and their social and material surroundings. Sandwall $(2010,2013)$ has used an ecological approach in her study of second language learning in work placements, and Virtanen (2013) draws on the approach in her study of Finnish language learning during practical training. In the present study, the participant's workplace is explored as a semiotic budget that offers the learner resources from which (s)he selects those that are meaningful for their language learning potential. The methods of analysis are discussed in the next section.

\section{Methodology and data}

\subsection{Nexus analytical approach to workplace ethnography}

Nexus analysis (Scollon and Scollon 2004) is applied here as an analytical framework to investigate workplace ecology and ethnography. It is a broad 
meta-methodology that calls for multi-methodology, and therefore scholars have applied it in various ways, drawing on methodological tools from linguistic ethnography, discourse analysis, interactional sociolinguistics, social semiotics and narrative approaches (see Lane 2014: 17; Pietikäinen 2010, 2012; Hult 2010; Kauppinen 2014). Tapio (2013) has already combined nexus analytical methodology with ecological language learning studies, and Hult (2010) and Compton (2013) have combined it with ecologically oriented research on language planning and policy.

Nexus analysis focuses on social action, and in the present study, Finnish language learning opportunities in a cleaning job was located as the social concern. In its analysis of ethnographical data, this study draws on linguistic ethnography (Heller 2008; Rampton et al. 2014). The data were gathered during a two-month period of fieldwork in 2013 at the participant's workplace. The focal actor, Kifibin, works for a big cleaning corporation which provides cleaning services for businesses. The data consist of participant observations and field notes, audio-recorded interaction, ethnographic interviews, and photographs. I shadowed Kifibin during nine working days and observed and recorded his work tasks and the interactions he had with his workmates. To deepen the knowledge acquired in the field, I conducted interviews with Kifibin and with his manager and two supervisors. Kifibin also took photographs of work situations that he considered meaningful for his L2 learning process. ${ }^{1}$

The research process included three phases: engagement, navigation and change (Scollon and Scollon 2004: 152-178). In order to engage with the social issue and identify the most relevant social actions connected to it, I read the research literature, interviewed immigrant cleaners and managers of cleaning companies, and wrote detailed field notes of my observations at the workplace. Navigating is the main stage of analysis, which in the present study meant analysing the interaction order of meaningful situations and tracing the connections between those moments and the people and mediational means involved in them (examined in more detail in Section 5). The final stage is to analyse change in the field through re-engagement and negotiations with the participants (see Section 6).

1 The study was conducted in the context of a research project 'Finnish as a work language: A sociocognitive perspective to work-related language skills of immigrants', funded by the Emil Aaltonen Foundation. An informed consent was obtained from the employers and the participants to carry out the research and disseminate the results. All the names have been changed and some details have been removed to ensure the anonymity of the participants and companies. Kifibin gave his consent for the publication of the photographs he had taken. 
After engaging with the research topic and the data, I chose to focus on analysing interaction order, since it is closely bound up with language learning opportunities. The concept 'interaction order' comes originally from the work of Goffman (1959, 1971, 1983). Scollon and Scollon (2003, 2004) have adopted Goffman's work as a starting point and developed it further in their research. Simply put, it refers to the different social arrangements through which people form relationships in social interactions (Scollon and Scollon 2004: 13). Interaction order is primary when the participants are physically present in the same space (face-to-face interactions) and secondary when it is mediated between participants, e.g. through technology or texts (Scollon and Scollon 2004: 51). To be able to attend to the various kinds of interaction orders and the constraints and affordances embedded in them, I pay particular attention to the ways in which the participants use material mediational means in interaction. The term 'mediational means' - in other words, 'cultural tools' - comes primarily from the work of Vygotsky (1978), since further developed, particularly by James Wertsch (1991). It refers to everything that mediates action, and can be divided into technical tools, which are material objects such as books or technologies, and psychological tools such as language (Jones and Norris 2005: 49). In this study, the emphasis is on the material objects which enable action.

The activities of the researcher also need to be examined closely (Scollon and Scollon 2004: 17). I have not intended to detach my presence in the field from the data and findings. In addition to my status as a native Finnish speaker and Finnish language teacher-researcher, it is important to note that I was Kifibin's teacher in 2012, when he took a Finnish language course at the university. I conducted the fieldwork at Kifibin's workplace a year after the course. Hence, we initially had a teacher-student relationship, which influenced the research setting (see also Simon-Maeda 2009: 106).

\subsection{The focal participant}

The focal participant of the study is Kifibin, a young Ugandan man, whose mother tongue is Luganda and who was educated through the medium of English. He gained a Bachelor's degree in natural sciences in a local university and worked in a water company in Uganda after graduation. He wanted to study further and decided to come to Finland because an intern in the water company had reported good experiences with Finnish education. In 2010 he moved to Finland to take an international Master's Program in natural sciences at a Finnish university. To finance his stay, Kifibin took a part-time job in a cleaning company alongside his studies. Although the language of instruction in international programs is 
English, he also took two Finnish language courses at the university (beginner's levels A1 and A2 in CEFR, see Council of Europe 2011). He was a motivated student and attended every lesson, three times a week, because he wanted to stay in Finland after completing his studies. Kifibin spoke Finnish outside the classroom too: he played soccer in a Finnish team and talked sometimes in Finnish with the team members, both face-to-face and in social media. Otherwise, he mostly used English and sometimes his mother tongue in his leisure time.

In 2012, Kifibin graduated and moved within Finland to a bigger city, attracted there by better employment opportunities. At the same time, he tried to find opportunities to study for a PhD in Finland, because his dream was to be a university lecturer and researcher. However, the supervisor of his Master's thesis was unable to get funding for his research projects and there was therefore no funding for Kifibin to start full-time doctoral studies. He did not succeed in finding a job in his field of expertise, either; instead, he continued his work as a cleaner, now full-time in two cleaning companies.

Kifibin wanted to learn more Finnish because he believed that a good knowledge of the language is a key to engaging in and becoming a part of Finnish society and the Finnish labour market. However, he no longer had time to take any language courses because he was holding down two jobs. Instead, he tried to use and learn the Finnish language at work, but as he was still a beginner, this meant at first mostly short sentences and simple topics. During the follow-up period, his language skills developed and he was able to talk about more complex topics and form longer sentences. Besides work mates, he had no Finnish friends or family with whom to speak Finnish. He continued playing soccer, but this time in a team that consisted of African players.

In one of his jobs he worked from 6 am till $1 \mathrm{pm}$, and in the other from $2 \mathrm{pm}$ till $6 \mathrm{pm}$. This case study was conducted at the workplace where he cleaned in the morning. Having introduced the focal participant, I will now analyse his cleaning routine and interaction order within his work community.

\section{Navigating language learning in a cleaning job: Affordances and constraints}

\subsection{The isolation of the cleaning routine within outsourced services}

Kifibin's work included cleaning in restaurants, offices, toilets, halls, and changing rooms. He was usually the only cleaner working on the premises of the 
client in question. It was only on extremely busy days that other cleaners from the company were allocated to help him carry out the cleaning tasks. He had two supervisors (a cleaning manager and a cleaning supervisor) who had 70 subordinates, one-third of them immigrants. They visited the clients' premises only occasionally, to give instructions, bring detergents and cleaning equipment or check the quality of the cleaning work.

Kifibin's workdays followed the weekly routine given to him by his employer. Every morning he started his workday at 6 am in a restaurant and three times a week he cleaned in offices after that. Otherwise, he worked in empty rooms and halls where he did not usually encounter anybody. Cleaners often work either early morning or late evening because clients prefer cleaning tasks to be carried out when employees are not present. It is also easier for cleaners to do their work in empty rooms.

During his workdays, Kifibin had very limited opportunities to interact with his workmates. Sometimes he exchanged a word or two with the waitress in the restaurant, but generally any communication with his workmates was limited just to greetings. In the excerpt below, Kifibin describes his work in the offices.

Example 1. Interview with Kifibin, at the end of the fieldwork (in English)

Maiju: you can describe the situation. you are three times per week there [at the offices]

Kifibin: actually there there is no interaction

Maiju: $\quad \mathrm{mm}$. I have noticed

Kifibin: basically not at all. I just go, clean and walk out.

Kifibin went to the offices early in the morning, before $8 \mathrm{am}$, mopped the floor in the corridor, quickly cleaned the small office rooms and took out the trash. Although most of the offices were empty, usually some of the office workers were starting their day and having coffee when he was there. Sometimes the employees greeted Kifibin and sometimes ignored him while they talked to other office workers. Due to their mutual attention at coffee breaks, the office workers clearly formed $a$ with, a group of people who are perceived as being together with each other (Scollon and Scollon 2003: 61; Goffman 1983). The cleaner was excluded from the group, with the exception of one office worker, a middle-aged Finnish man, who had offered Kifibin coffee a couple of times and who Kifibin described as "different" from the others. Otherwise, the office workers clearly did not regard the cleaner as a member of their work community. If they had any requests about cleaning, they usually did not communicate their wishes directly to him, but informed their manager instead. For example, when they wanted to add vacuuming under the carpet to the cleaning routine, they never mentioned it to Kifibin when he was cleaning there. 
The fact that the cleaner was not on the client's payroll inevitably affected the employees' attitudes. The next excerpt from an interview with the restaurant manager, Kaija, illustrates the complexity of outsourced services. Kaija was a contact person responsible for communication between the cleaning company and the client company. In the interview excerpts, the most significant parts for the analysis are bolded.

Example 2. Interview with Kaija, (originally in Finnish, my translation)

Maiju: $\mathrm{mm}$. so in what kind of matters do they [cleaners] usually deal with you. or there is actually only one cleaner here now, so he

Kaija: well if there are some changes or there are some questions or something like that comes up. exceptions to the normal pattern so. they work quite independently though. and of course it's what we aim at. because actually the cleaning is outsourced and the supervising is outsourced, too, so it should disturb our work as little as possible so to say. so the cleaner should be like very invisible ((gives a laugh))

Maiju: mm yes. so do you usually contact his managers if there are some big changes or how does it

Kaija: well I have the habit that of course I like to shout out immediately when I see like I did today too, that now are you aware that something special is coming that it [the weekly routine] isn't following the typical rhythm. and of course I need to contact their managers too so that the billing patterns and other stuff will be correct to avoid conflicts like who and what

Within the client company, Kaija was the one who dealt with the cleaning company. However, it was not her task to supervise the cleaner because the supervising is outsourced, too. Because Kaija's office was in the same building where Kifibin cleaned every day, she did sometimes tell him directly about any extra cleaning tasks, usually in English. However, it was more important to inform the cleaning company, to avoid any problems with the billing. If there were any changes to the normal cleaning routine, Kaija informed the manager of the cleaning company via email first, who then called Kifibin's supervisor, who finally explained the changes to Kifibin, often over the phone (see Figure 1). Outsourcing

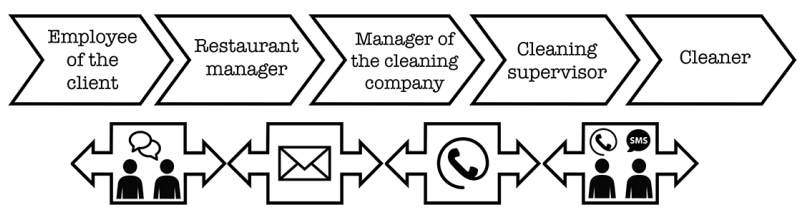

Figure 1: The chain of messages: An example of how requests to the cleaner were relayed. 
the services therefore affected the interaction order between the cleaner and others: the client's employees did not usually communicate directly with the cleaner but acted through an intermediary instead. Besides being indirect, the interaction order was mainly secondary, as the messages were often relayed via different mediational means such as email, phone calls and text messages.

As a result of subcontracting and outsourcing their cleaning services, some clients might want cleaners to be invisible, work independently and disturb their work as little as possible, as Kaija states in the interview. The employees in the workplace did not offer affordances for active participation on the part of the cleaner. Because the services were outsourced, Kifibin neither took part in the client's social events nor met other cleaning staff on a daily basis. My observations and interviews show that Kifibin did not have many opportunities for language socialization at work.

Another reason for exclusion might have been language skills. Lønsmann (2014) argues that employees can be excluded from informal interactions on the basis of language skills. Here, the clients did not know much about Kifibin, not even about his language repertoire. Kifibin speaks English fluently and is also able to communicate in Finnish. Kaija, for instance, admitted that she did not know at first that Kifibin was able to communicate in Finnish. Duchêne (2011) showed in his ethnographic research within an international airport that invisible roles are often allocated to immigrants, which means that their multilingual repertoires remain mostly invisible, too.

Due to the silent nature of his work, Kifibin tried to get more opportunities for language learning by listening to the radio during his work. In the interview he described the benefits of this as follows:

Example 3. Interview with Kifibin, at the end of the fieldwork (in English)

Kifibin: like I said that because in [the workplace] probably, the fact that there are few people around, and I'm always alone so I get to listen to radio almost every day. so that has also been good for me to learn different different like phrases or even as well listening, especially listening, and trying to understand different topics when people are talking about different situations.

Radio was a significant mediational means for Kifibin to fill in his workdays with meaningful linguistic resources. In my field notes, there are many references to his comments about radio programs. He listened to the radio most of the time while he cleaned, preferring radio journalists who spoke clearly and slowly enough for him to follow. He focused on listening to the Finnish language, and he often asked about words or structures he had heard on the radio. He concentrated on the 
different topics the journalists talked about and sometimes picked a culturebound topic from the radio and discussed it with me. By linking linguistic structures to different situations he got ideas about how to use the language himself. That is how he linked the linguistic resources to the social context and used them as affordances (van Lier 2000) for learning to understand the language.

\subsection{Interaction with significant others at the workplace}

In this section, two interaction situations are analysed to show what kinds of language learning potentials cleaning work might afford. In spite of the lonely and non-linguistic nature of cleaning work, some opportunities for second language interaction did arise for Kifibin. In the interview, he mentioned a few significant others at the workplace: his supervisors, who offered him support, and a waitress called Pirkko, who always acknowledged him in a friendly manner and offered him coffee. She had brief chats with Kifibin about the weather or what was going on in the workplace.

The first situation takes place in the restaurant where Kifibin's workday started every morning before opening hours. Usually the cook, a middle-aged Finnish man, was already at work in the kitchen, while Pirkko, an elderly Finnish woman, came in at 7 am. In the situation presented below, Kifibin is cleaning in the kitchen and Pirkko is working near him. The excerpt begins when Kifibin takes out a full bag of organic waste. Organic waste had not been collected separately in the kitchen before. The language used in the situation is mostly Finnish, but some English is also used. English translations are given below the original utterances, and utterances in English are highlighted with asterisks $\left(^{\star}\right)$.

Excerpt 1: "How can you call the roll?"

Participants: Kifibin, Pirkko, Maiju

Place: The restaurant kitchen

01 Kifibin: teillä on nut biojäte ((takes bio bag away))

02 you have bio trash now ((takes bio bag away))

Pirkko: joo

yeah

03 Kifibin: hyvä

good

04 Pirkko: hianoo (.) mä löysin tuolta komerosta (.) [pussin great (.) I found in a closet over there (.) [a bag 
06 ((Kifibin carries the full trash bags from the kitchen to the cleaning cupboard. He tries to find something in the cupboard. Pirkko stays in the kitchen.))

07 Kifibin: *she said* siivouskomero

${ }^{*}$ she said* the cleaning cupboard

08 Maiju: mm siivouskomero $\mathrm{mm}$ the cleaning cupboard

09 Kifibin: joo (.) mutta mä en näe mitään yeah (.) but I don't see anything

10 Maiju: mitä sä etsit what are you looking for

11 Kifibin: biojäte bio trash

12 Maiju: aaa (.) sanoko se että se löysi jostain (.) tuolta komerosta en tiiä (.) ehkä sä voit kysyä ((laughing))

aa (.) did she say that she found it somewhere (.) in the cupboard there I don't know (.) maybe you can ask ((laughing))

13 ((Kifibin and the researcher are walking from the cleaning cupboard towards the kitchen.))

14 Kifibin: *how can you call the roll?*

15 Maiju: rulla

roll

16 Kifibin: rulla

roll

17 ((Kifibin goes into the kitchen.))

18 Kifibin: hei anteeksi (.) missä rulla on? excuse me (.) where is the roll?

19 Pirkko: (- inaudible - )

20 ((Kifibin laughs.))

21 Pirkko: mutta se on aika tyhjä (.) anna olla but it's quite empty (.) forget it

22 ((Pirkko shows anyway where she found the roll. It is in a cupboard in the kitchen. She gives it to Kifibin.))

23 Pirkko: no tässähän nyt tämä (-inaudible-) rulla (.) paaksä tän sinne? well here it is. (- inaudible -) the roll. will you put it there?

24 Kifibin: ookoo kiitos okay thank you

25 ((Kifibin puts a bio bag in the organic waste trashcan.)) 
The excerpt shows how Kifibin manages a problem-solving situation. It is his duty to take out the full bio trash bag and put a new one into the organic waste trashcan, but because the material tools in the kitchen have changed, Kifibin comments on the unusual setting to Pirkko in line 1. Pirkko replies and explains that she found a bio bag in a cupboard (line 04). Usually, all the cleaning equipment, detergents and trash bags are in the cleaning cupboard. So Kifibin assumes that Pirkko means that cupboard and tries to find the roll of bags there (line 06). He is surprised when the roll is not there and wonders out loud if Pirkko said siivouskomero (cleaning cupboard, line 07). I respond that Pirkko may have meant another cupboard and suggest he should ask about it (line 12). In order to ask for it in Finnish, Kifibin checks how to say roll in Finnish (line 14). After that, he asks Pirkko where to find the roll (line 18) and Pirkko gives it to him (line 22).

During the recorded situation, a lot of movement is going on. The excerpt thus illustrates that language use in cleaning work is an embodied practice and is often interwoven with work tasks. In the situation above, Kifibin comments on the task he is performing at that moment (line 01), and the purpose of asking a question (line 18) is to complete the task successfully. At work, Kifibin utilizes his linguistic repertoire by using both English and Finnish. Because Pirkko does not share any other linguistic resources with Kifibin than Finnish (she does not use English), Kifibin always speaks Finnish with her, even though it is difficult for him. To get through the interaction situation in the excerpt, he thus utilizes the ethnographer as an English-Finnish "living dictionary" before talking to Pirkko in Finnish (line 14, see also Suni 2010: 49).

The immediate social surroundings afford many relevancies that can be used for the social actions that an individual is engaged in (van Lier 2000: 252). Language learners select the affordances that are meaningful to them and the action they are carrying out. Kifibin's purpose is to change the bio trash bag, and to complete the task he exploits the linguistic repertoire of the ethnographer who is walking beside him with a tape recorder. Hence he gets to know the Finnish word rulla that is necessary in the following interaction section with Pirkko (line 18). In nexus analysis, as the ethnographer is a participant in the social action, research activities merge with participation activities; this can mean other actors changing their actions somewhat when a researcher is in the field (Scollon and Scollon 2004: 156). Owing to our previous experiences in the classroom and our historical roles as a language teacher and a student, Kifibin turns to me when he has questions about the Finnish language, and I accordingly act as a supporter offering a possible way to solve the problem (line 12). Unfortunately, he did not usually have anybody to turn to in problematic situations at the workplace and he therefore missed many chances to interact 
with his workmates. If Kifibin did not know how to ask Pirkko about the work task or how to react to her comments, the interaction often stopped there, probably because he was unable to use the affordances available to manage the situation.

Although his conversations with Pirkko were short, they nevertheless constituted rare opportunities for Kifibin to interact with the client's employees. During the research period, Pirkko unexpectedly stopped showing up at her workplace, and somebody else was hired in her stead. The replacement did not acknowledge Kifibin's presence or serve him coffee. Kifibin did not know what had happened to Pirkko. Due to her absence, opportunities for interaction in the restaurant decreased during the fieldwork period. In the absence of Pirkko, the supervisors from the cleaning company were basically the only workmates who interacted in Finnish with the cleaner.

In Excerpt 2, a cleaning supervisor (Katri) is giving Kifibin instructions about new tasks that have not been part of his usual cleaning routine. She is visiting Kifibin for half an hour to explain face-to-face the extra tasks for the coming weeks. The excerpt below begins when Katri has already been giving instructions for seven minutes and now remembers the last point she needed to tell him about. The situation was recorded two weeks after the previous one.

Excerpt 2: “How many, one roll?"

Participants: Kifibin, Katri

Place: a kitchen on the client's premises

01 Katri: [Kifibin]

02 Kifibin: mm-m?

03 Katri: yks vielä (.) mä näytän sulle kalenterista one thing more (.) I'll show it to you on the calendar

04 ((Katri shows Kifibin a calendar.))

05 Katri: tällön ens viikon (.) viikon päästä perjantaina (.) tällön then next week (.) a week on Friday (.) then

06 ((Katri points to the date on the calendar.))

07 Katri: niin jätä Kaijalle tohon keittiöön niin noita sataviiskymppisiä roskapusseja

leave those 150-litre trash bags in the kitchen for Kaija

08 Kifibin: yhm

09 Katri: niin ne saa vaihtaa lauantaina jos on tarpeen kahvilassa so they can change them on Saturday if necessary in the café

10 Kifibin: ookoo okay 
11 Katri: niin kun jos tulee liian täyteen (.) niin jättää tollon heille sit roskasäkkejä

so that if they get too full (.) then you can leave them those trash bags

12 Kifibin: montako (.) yksi rulla

how many (.) one roll

13 Katri: kolme rullaa

three rolls

14 Kifibin: kolme

three

15 Katri: kolme rullaa (.) jätä varuks riittävästi (.) ne palauttaa ne sit three rolls (.) leave enough just in case (.) they'll return them then

16 Kifibin: ookoo

okay

Excerpt 2 is an example of a typical linguistic situation in cleaning work: taking instructions. Typical and regular cleaning tasks do not require much linguistic performance, but when the daily routine changes in some way, cleaners needs to understand their instructions. Sometimes they must also ask for clarification if they are unsure about the tasks, as happens in both the above excerpts.

The interaction order in the excerpt above is a hierarchical guiding situation, where the supervisor is higher in the hierarchy: she is the one who has the knowledge and power, and the task of the cleaner is to listen carefully and act according to orders. The situation requires more comprehension than production skills from the cleaner; it is very important to understand how to carry out the tasks. The supervisor often illustrates the instructions, as in line 4: she uses her calendar as a mediational means by pointing to the date when the task needs to be performed, and thus the calendar becomes an affordance for mutual understanding. The function of most of Kifibin's comments is to agree and show that he has understood the instructions (in lines 08, 10, 16). His reactions are very short and simple (yhm, okay), and the supervisor seems to be satisfied with them: they show comprehension. In addition to confirming that he has understood what is said, the cleaner needs to know how to ask for clarification and check the details. In line 14 Kifibin partly repeats Katri's answer to make sure of the quantity. Altogether, in situations where supervisors give instructions, they talk more and the cleaner mostly listens. Consequently, Kifibin believed that he had more opportunities to practice listening than speaking in his work.

However, some progress at least is shown in production as well. The situation above occurred two weeks after the first excerpt and now Kifibin uses the Finnish word rulla to find out if one roll is enough (in line 12). In the first 
situation he needed support because he did not remember or know how to say roll in Finnish, but in the second one he uses the word with ease. Van Lier (2007) proposes that learning should be motivated by a learner's practical needs. The learner tests his tentative hypothesis in a language-using experience, remembers this learning experience, and prepares to utilize it appropriately on future occasions (van Lier 2007: 56). I would argue that when learner needs to know a word in a situated embodied social action they are engaged in, such as in the first situation, it is more probable that they will remember it and know how to use it in similar contexts.

\section{Changes in the nexus: Becoming aware of learning opportunities}

As the Scollons (2004: 178) emphasize, an ethnographer's actions alter trajectories for people in the field, which in turn produces social change. The last phase in the analysis is re-engagement, which means going back to the field and engaging in negotiations with the focal social actor(s). Kifibin was involved in the process of analysis as the findings were negotiated with him in an interview at the end of the fieldwork. He also read the manuscript of this paper and commented briefly on the results via email. In the excerpt below, he gives his views on the social issue in focus in this study: opportunities for Finnish language learning at work.

Example 4. Interview with Kifibin, at the end of the fieldwork (in English)

Maiju: so what do you think in general, have there been opportunities to learn Finnish in your cleaning work and what opportunities and why. this is a really large question but

Kifibin: yeah I think, the opportunities are, actually ever ever since that you began coming here, and then you interacted with with my bosses. since then they've been using more Finnish when they are interacting with me. and I think my my listening is is improving. and my interaction with people is also improving. so. and now that I'm more keen on on the Finnish around me. I think I'm I'm having more opportunities to learn. more things.

When I started the fieldwork, I explained the research topic (Finnish language learning and work community support in entrance jobs) to the participants, and some of them changed their practices as a result of my study. Kifibin's supervisors started to use more Finnish instead of English when they gave Kifibin 
instructions, probably because my topic was Finnish language learning. Moreover, Kifibin also changed his practices at work. He told me that he began to be more aware of the Finnish resources in the environment. To locate the relevant social actions for the research problem, I asked him to tell me about meaningful opportunities he had for language learning and to take pictures of the meaningful learning situations in the workplace. In consequence, he started to take more notice of the texts surrounding him when he cleaned. In figure 2, there is a picture he took - a sign that says: "Please inform the staff if the roll runs out". The context (a picture taken by the researcher) is presented beside it: the text is on a roll towel dispenser in a restroom.
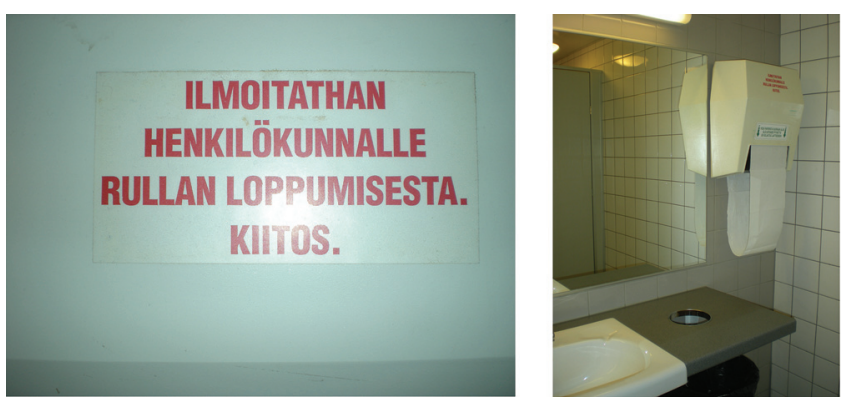

Figure 2: Photographs: The text in its context.

When we were going through the pictures Kifibin took, I asked him why he had taken this photo. Below, he explains his view about the sign and the photography exercise as learning potentials (Finnish utterances are italicized and explanations are given in brackets).

Example 5. Interview with Kifibin, at the end of the fieldwork (in English)

Kifibin: this one I took it from, from that toilet in a hall. from this hand machine. hand paper machine. and then, basically I was also interested in the sentence phrase. like if you are being polite, ilmoitathan. [please inform]. then, mistä [elative case] like henkilökunnalle [to the staff; the word is in the allative case] - and then, lullan loppumisesta [about the roll running out; the words are in the elative case]. like mistä [elative case]. like what topic are you talking about.

Maiju: do you want to say something about pictures. how it was to take

Kifibin: I think it was. it was fun. taking them. and perhaps it's it's something that I noted that you also can learn from notices. different sentence structures 
The interview excerpt shows that signs at the workplace became affordances for Kifibin: he believes that he started to be more aware of them and to use them for language learning. As the Scollons (2004: 162, 2003: 205) emphasize, some aspects of the place are central and foregrounded for social actions while others are backgrounded. Van Lier (2000: 252) notes that only engaged learners perceive actively linguistic affordances in their surroundings and use them for (linguistic) action. Due to the participant photograph task, Kifibin started to focus on the signs surrounding him in different locations in his workplace, and he began to use them for language learning purposes. He is an analytical person, and he often concentrated on the structures and forms of words. Finnish is an agglutinative language with an extensive inflectional morphology, which means that the endings and suffixes of words are significant in meaningmaking and understanding (Suni 2007: 221, 2008). Kifibin mentions two different cases (the elative and the allative case) as targets of learning. He also uses notices to learn polite ways of using the Finnish language. In material artifacts, such as in this sign, there are structures, vocabulary and phrases that are conventionally used within a certain language community and therefore provide culturally and historically shared ways to express issues in a specific situation (Dufva 2013: 68). Kifibin was interested in the ways that politeness was expressed in the sign through different structures.

The photographs also illustrate the independent and lonely track that Kifibin had for language learning at work, as none of the photographs included any people. He took ten pictures, all of semiotic resources: signs, notes and advertisements. On the one hand, the pictures point to a very lonely image of the language learning potentials he encountered at work. On the other hand, notices work as material tools in secondary interaction order (Scollon and Scollon 2004: 50), because they are essentially messages from one person to others. That mediated social aspect might have helped Kifibin to learn from the notices. Either way, signs afford only rather limited opportunities for learning production skills, and therefore their pedagogical value is perhaps not very high.

The ethnographer's presence in the field increased the number of social situations in Kifibin's working day. When I was observing his work, we talked in Finnish and if he had difficulties understanding or constructing something, he asked me. There were a couple of situations when Kifibin asked me words to use in interaction, such as "rulla" in Excerpt 1. For instance, once he wanted to know how to say "terrace" in Finnish, and after that asked the waitress if the restaurant terrace was already open. More often, however, he asked me about phrases or structures he had heard on the radio and wanted to know how to use them in different contexts. Our historical roles as language teacher and language learner affected our interactions throughout the research process. Altogether, 
the fieldwork changed the practices of Kifibin and his supervisors, which increased the opportunities Kifibin had to use and learn Finnish. The fieldwork can therefore be seen as an application of how to support language learners to notice, use and learn language at work.

Changes in the field are often unpredictable for the researcher as well. During the research process, the contract between the client and the cleaning company was terminated and Kifibin started to work for another client, in a shopping mall. Due to fierce price competition in the cleaning industry, efficiency norms have been tightened and contracts between cleaning companies and their clients are terminable and unstable (Herod and Aguiar 2006: 428). As a result, the places, people and discourses that Kifibin was already familiar with were left behind and he began to work in a new environment.

In a follow-up interview a year after the fieldwork was over, Kifibin told me that in spite of his language development ${ }^{2}$ he was still working as a cleaner and had not been given any new responsibilities at work. Even though he had been cleaning for four years by then, he still considered it to be a temporary way of making his living. Kifibin's story is an example of the difficulties that immigrant cleaners often face: he works in a tight niche that is hard to expand, as even linguistic capital does not seem to help him enter into the broader labour market. If learners invest in a second language, they do so in the hope of acquiring a wider range of symbolic and material resources that would increase their cultural capital and social power (Norton Peirce 1995: 17). For Kifibin, this has not yet happened.

\section{Conclusions}

This ethnographic case study suggests that a cleaning job may offer only very limited opportunities to learn a second language. As a result of the outsourcing of cleaning services, this cleaner was rather isolated from the work community of the cleaning company, and worked instead on the business premises of the client, where he was not recognized as a member of the work community. Moreover, he had very limited access to the linguistic affordances circulating among the Finnish workers in the workplace. Participation in work activities and

2 Kifibin took a National Certificate of Language Proficiency test (FNBE 2014) a year after the fieldwork. His overall result was level 3, which is equivalent to level B1 in the CEFR (see Council of Europe 2011). His listening comprehension, speaking, and reading comprehension were at level 3 (B1), and writing at level 4 (B2). This was a clear improvement, as he had taken language courses only to level 2 (A2). 
access to support are not afforded evenly to all workers, but instead might depend on employment status, personal relations or individual factors such as gender or race (Billet 2001: 210). To encourage clients to become acquainted with a new cleaner, cleaning supervisors could introduce a new employee to them. Their language skills could be introduced too, as it seems that clients are not always aware of the language proficiency of the cleaner. That might make the cleaner more visible in the eyes of clients, which could increase the communication between them.

The interaction situations analysed in this case study showed that the most common linguistic practices in cleaning work were taking instructions and asking for clarification. Routine cleaning tasks did not include linguistic performance, but changes in cleaning practices and new work tasks required interaction with supervisors. However, the interaction order was indirect because the instructions are relayed through intermediaries. Furthermore, the interaction order of briefing by the cleaning supervisors was secondary when the communication was mediated through technology (see Scollon and Scollon 2004: 51). The amount of primary face-to-face interaction and support available to the cleaner at work therefore depended heavily on the people who worked on the client's premises. In this study the system of outsourcing contributed to the cleaner's isolation, and more research is needed to reveal the multiple and complex effects that privatization may have in different contexts.

This analysis of interaction situations at work shows that some learning opportunities can open up, even if the amount of interaction is limited. Learning is not dependent on the quantity of linguistic resources alone, but also on their meaningfulness. When learning is embodied and situated, as work-related learning often is (Beckett and Hager 2002), resources may become meaningful affordances for the learner. Unfortunately, in this case, the learner was left alone and there was nobody who regularly supported his language-learning process. The fieldwork increased the participant's learning opportunities owing to the teacher-learner relationship of the ethnographer and the participant. If Kifibin had been paired with a Finnish-speaking worker able to answer his questions, he could have utilized second language learning opportunities at work more efficiently.

From an ecological perspective, the capacity to perceive and focus on learning opportunities is a prerequisite for language learning (van Lier 2004). Therefore, in work-related pedagogy, it is essential to guide learners to notice and utilize affordances in their work environments. A participant photograph task, like the one applied in this case study, can benefit language learners by guiding their perception toward the linguistic affordances that are available in their immediate working surroundings. However, the pedagogical value of signs 
is limited, and it is often more challenging to find opportunities to interact in a second language. In future research, more strategies for increasing opportunities to use and learn a local language in language-marginal jobs need to be developed. ${ }^{3}$

In conclusion, it is essential to question why immigrants are over-represented in the cleaning industry in the first place. While the Finnish Government (2006: 3, 2015: 34) aims to recruit work-related immigrants due to labour shortages, the position in the labour market of immigrants whose residence permit is dependent on being employed is especially precarious and unfair, as they need to have a specified minimum number of working hours to be able to stay in the country (Könönen 2015: 114). Many students from outside the EU countries would like to stay in Finland after graduation, but in order to renew their residence permit they have to find a job within six months (Aliens Act 301/2004: section 55, see Ministry of the Interior 2004: 18). As a result, they often need to remain in cleaning jobs, because leaving one job to hunt for another would be too risky. Therefore, cleaning is in fact often a dead-end job instead of a means of entry into the broader labour market, especially for immigrants in the most precarious position.

Acknowledgements: I would like to sincerely acknowledge Professor Alexandre Duchêne who provided guidance and invaluable feedback during different phases of this manuscript preparation. I am very grateful for the project Finnish as a work language (funded by the Emil Aaltonen Foundation) for research grants, collaboration and support, particularly for my principal supervisor Minna Suni and my colleague Aija Virtanen. I would also like to thank my supervisor Sari Pietikäinen and the participants of Discourse Studies Article Writing Programme organised by Peripheral Multilingualism Project for their encouragement and helpful comments. Furthermore, I wish to extend my thanks to the two anonymous reviewers who offered insightful suggestions on the earlier version of this paper and to Kifibin for his time and commitment.

\section{References}

Angouri, Jo. 2014. Introduction. Multilingualism in the workplace: Language practices in multilingual contexts. Multilingua 33(1-2). 1-9.

Atkinson, Dwight (ed.). 2011. Alternative approaches to second language acquisition. New York: Routledge.

3 See Roberts et al. (2001) for ideas on how to guide language learners to make observations about the target language in their social surroundings. 
Barab, Sasha \& Wollf-Michael Roth. 2006. Curriculum-based ecosystems: Supporting knowing from an ecological perspective. Educational Researcher 35(5). 3-13.

Beckett, David \& Paul Hager. 2002. Life, work, and learning: Practice in postmodernity. London: Routledge.

Block, David. 2003. The social turn in second language acquisition. Edinburgh: Edinburgh University Press.

Billet, Stephen. 2001. Learning through work: Workplace affordances and individual engagement. Journal of Workplace Learning 13(5). 209-214.

Compton, Sarah. 2013. Implementing language policy for deaf students in a Texas school district. International Multilingual Research Journal 7(2). 138-154.

Council of Europe. 2001. Common European framework of reference for languages: Learning, teaching, assessment. Cambridge: Cambridge University Press.

Duchêne, Alexandre. 2011. Neoliberalism, social inequalities, and multilingualism: The exploitation of linguistic resources and speakers. English translation of Néolibéralisme, inégalités sociales et plurilinguisme: l'exploitation des ressources langagières et des locuteurs. Langage \& Société 136. 81-108.

Duchêne, Alexandre, Melissa Moyer \& Celia Roberts. 2013. Language, migration and social inequalities: A critical sociolinguistic perspective on institutions and work. Bristol: Multilingual Matters.

Duff, Patricia, Ping Wong \& Margaret Early. 2000. Learning language for work and life: The linguistic socialization of immigrant Canadians seeking careers in healthcare. Canadian Modern Language Review 57. 9-57.

Duff, Patricia. 2007. Second language socialization as sociocultural theory: Insights and issues. Language Teaching 40. 309-319.

Duff, Patricia. 2008. Language socialization, higher education, and work. In Patricia Duff \& Nancy Hornberger (eds.), Encyclopedia of language and education. Vol.8: Language socialization, 257-270. New York: Springer.

Dufva, Hannele. 2013. Kognitio, kieli ja oppiminen: Hajautettu näkökulma. [Cognition, language and learning: A distributed view]. In Tiina Keisanen, Elise Kärkkäinen, Mirka Rauniomaa, Pauliina Siitonen \& Maarit Siromaa (eds.), AFinLA-e: Soveltavan kielitieteen tutkimuksia 5, 57-73. http://ojs.tsv.fi/index.php/afinla/article/view/8739 (accessed 29 October 2014).

Dufva, Hannele, Minna Suni, Mari Aro \& Olli-Pekka Salo. 2011. Languages as objects of learning: Language learning as a case of multilingualism. Apples - Journal of Applied Language Studies 5(1). 109-124. http://apples.jyu.fi/article_files/v5-8_Dufva_et_al_final. pdf (accessed 29 October 2014).

Finnish National Board of Education (FNBE). 2014. National Certificates of Language Proficiency (YKI). http://oph.fi/english/services/yki (accessed 22 August 2014).

Gibson, James. 1979: The ecological approach to visual perception. Boston: Houghton Mifflin. Goffman, Erving. 1959. The presentation of self in everyday life. New York: Doubleday.

Goffman, Erving. 1971. Relations in public. New York: Harper and Row.

Goffman, Erving. 1983. The interaction order. American Sociological Review 48(1). 1-17.

Goldstein, Tara. 1997. Two languages at work: bilingual life on the production floor. Berlin; New York: Mouton de Gruyter.

Finnish Government. 2006. Hallituksen maahanmuuttopoliittinen ohjelma: valtioneuvoston periaatepäätös 19.10.2006 [Government migration policy programme: Government resolution of 19.10.2006]. Työhallinnon julkaisuja 371. Helsinki: Ministry of Employment. 
Finnish Government. 2015. Valtioneuvoston tiedonanto eduskunnalle 29.5.2015 nimitetyn pääministerin Juha Sipilän hallituksen ohjelmasta. [Bulletin from the Government to the Parliament about the government platform by the Juha Sipilä's parliament designated 29.5.2015]. Helsinki: Council of State. http://valtioneuvosto.fi/documents/10184/1433371/ Tiedonanto_Sipil\%C3\%A4_29052015_final.pdf/6de03651-4770-492a-907f-89452141d0d5 (accessed 17 June 2015).

Heller, Monica. 2008. Doing ethnography. In Li Wei \& Melissa Moyer (eds.), Blackwell guide to research methods in bilingualism and multilingualism, 249-262. Oxford: Blackwell.

Herod, Andrew \& Luis Aguiar. 2006. Introduction: Cleaners and the dirty work of neoliberalism. Antipode 38(3). 425-434.

Hult, Francis. 2010. Analysis of language police discourses across the scales of time and space. International Journal of the Sociology of Language 202. 7-24.

Jones, Rodney \& Sigrid Norris. 2005. Discourse as action/discourse in action. In Sigrid Norris \& Rodney Jones (eds.), Discourse in action: Introducing mediated discourse analysis, 3-14. London: Routledge.

Kauppinen, Kati. 2014. Welcome to the end of the world! Resignifying periphery under the new economy: A nexus analytical view of a tourist website. Journal of Multicultural Discourses 9 (1). 1-19.

Könönen, Jukka. 2015. Tilapäinen elämä, joustava työ: rajat maahanmuuton ja työvoiman prekarisaation mekanismina [Temporary life, flexible work: Borders as mechanisms of precarisation of immigration and labour]. Joensuu: University of Eastern Finland.

Lane, Pia. 2014. Nexus analysis. In Jan-Ola Östman \& Jef Verschueren (eds.), Handbook of Pragmatics: 2014 Installment viii. John Benjamins.

Lantolf, James \& Steven Thorne. 2006: Sociocultural theory and the genesis of second language development. Oxford: Oxford University Press.

Lier, Leo van. 2000. From input to affordance: Social-interactive learning from an ecological perspective. In James Lantolf (ed.), Sociocultural theory and second language learning, 245-260. Oxford: Oxford University Press.

Lier, Leo van. 2004. Ecology and semiotics of language learning: A sociocultural perspective. Boston: Kluwer Academic.

Lier, Leo van. 2007. Action based teaching, autonomy and identity. Innovation in Language Learning and Teaching 1(1). 46-65.

$\mathrm{Li}$, Duanduan. 2000. The pragmatics of making requests in the $\mathrm{L} 2$ workplace: A case study of language socialization. Canadian Modern Language Review 57(1). 58-87.

Lønsmann, Dorte. 2014. Linguistic diversity in the international workplace: Language ideologies and processes of exclusion. Multilingua 33(1-2). 89-116.

McCall, Christopher. 2003. Language dynamics in the bi- and multilingual workplace. In Robert Bayley \& Sandra Schecter (eds.), Language socialization in bilingual and multilingual societies, 235-250. Clevedon: Multilingual Matters.

Mertz, Elizabeth. 2007. The language of law: Learning to think like a lawyer. Oxford: Oxford University Press.

Ministry of the Interior, Finland. 2004. Aliens Act 301/2004. https://www.finlex.fi/en/laki/ kaannokset/2004/en20040301.pdf (accessed 17 March 2015).

Norton Peirce, Bonny. 1995. Social identity, investment, and language learning. TESOL Quarterly 29(1), 9-31.

Official Statistics of Finland (OSF). 2013. Employment [e-publication]. Industry, employer sector and jobs 2011, Appendix table 1. Most common occupational groups among employed 
persons aged 18 to 74 with foreign origin in 2011. Helsinki: Statistics Finland. http://www. stat.fi/til/tyokay/2011/04/tyokay_2011_04_2013-11-06_tau_001_en.html (accessed 31 March 2014).

Partanen, Maiju. 2013. Suomen kielen oppimisen mahdollisuudet ja työyhteisön tuki puhdistuspalvelualalla: Afrikkalaisten maahanmuuttajien käsityksiä ja kokemuksia [Finnish language learning opportunities and support from the work community at cleaning service: beliefs and experiences of African immigrants]. In Tiina Keisanen, Elise Kärkkäinen, Mirka Rauniomaa, Pauliina Siitonen \& Maarit Siromaa (eds.), Multimodal discourses of participation, 55-76. Jyväskylä: The Finnish Association for Applied Linguistics.

Pietikäinen, Sari. 2010. Sámi language mobility: Scales and discourses of multilingualism in a polycentric environment. International Journal of the Sociology of Language 202. 79-101.

Pietikäinen, Sari. 2012. Kieli-ideologiat arjessa. Neksusanalyysi monikielisen inarinsaamenpuhujan kielielämäkerrasta [Language ideologies in practice: A nexus analysis of a multilingual Inari Sámi speaker’s language biography]. Virittäjä 116(3). 410-440.

Piller, Ingrid \& Loy Lising. 2014. Language, employment, and settlement: Temporary meat workers in Australia. Multilingua 33(1-2). 35-59.

Rampton, Ben, Janet Maybin \& Celia Roberts. 2014. Methodological foundations in linguistic ethnography. Working papers in Urban Language \& Literacies 125. 1-25.

Roberts, Celia. 2010. Language socialization in the workplace. Annual Review of Applied Linguistics 30. 211-227.

Roberts, Celia, Michael Byram, Ano Barro, Shirley Jordan \& Brian Street. 2001. Language learners as ethnographers. Clevedon: Multilingual Matters.

Sandwall, Karin. 2010. "I learn more at school": A critical perspective on workplace-related second language learning in and out of school. Tesol Quarterly, 44(3). 542-574.

Sandwall, Karin. 2013. Att hantera praktiken. Om sfi-studerandes möjligheter till interaktion och lärande på praktikplatsen [handling practice - second language students' opportunities for interaction and language learning at work placements]. Gothenburg: University of Gothenburg.

Sarangi, Srikant \& Celia Roberts. (eds.) 1999. Talk, work, and institutional order: Discourse in medical, mediation and management settings. Berlin \& New York: Mouton de Gruyter.

Scollon, Ron \& Suzie Wong Scollon. 2003. Discourses in place: Language in the material world. New York: Routledge.

Scollon, Ron \& Suzie Wong Scollon. 2004. Nexus analysis: Discourse and the emerging internet. London: Routledge.

Simon-Maeda, Andrea. 2009. Working the hybridization: A case of bi- and multilingual speakers in Japan. International Multilingual Research Journal 3(2). 90-109.

Suni, Minna. 2007. Awareness of second language inflectional morphology: A case study of Finnish as a second language. Acta Linguistica Hungarica 54(2). 217-235.

Suni, Minna. 2008. Toista kieltä vuorovaikutuksessa. Kielellisten resurssien jakaminen toisen kielen omaksumisen alkuvaiheessa. [second language in interaction: sharing linguistic resources in the early stage of second language acquisition]. Jyväskylä: University of Jyväskylä.

Suni, Minna. 2010. Työssä opittua: työntekijän näkökulma ammatilliseen kieli- ja viestintätaitoonsa. [learned at work: an employee's perspective on their professional language and communicative skills]. In Mikel Garant \& Mirja Kinnunen (eds.), AFinLA-e: Soveltavan kielitieteen tutkimuksia 2. 45-58. Jyväskylä: Finnish association for applied 
linguistics. http://ojs.tsv.fi/index.php/afinla/article/view/3875 (accessed 15 September 2014).

Tapio, Elina. 2013. A nexus analysis of English in the everyday life of FinSL signers: A multimodal view on interaction. Jyväskylä: Jyväskylä University Printing House. http://users.jyu. fi/ elmamcca/phdthesis_files/PhDElinaTapio2013.pdf (accessed 29 October 2014).

Trux, Marja-Liisa. 2002. Diversity under the northern star. In Annika Forsander (ed.), Immigration and economy in the globalization process: The case of Finland, 175-225. Helsinki: Sitra.

Wertsch, J. V. 1991. Voices of the mind. A sociocultural approach to mediated action. Cambridge, MA: Harvard University Press.

Virtanen, Aija. 2013. Minä sairaanhoitajana: Tulevaisuuden minuudet motivaatiota muokkaamassa [I as a nurse: future selves making motivation.] Lähivertailuja - Lähivõrdlusi 23. 403-427. http://dx.doi.org/10.5128/LV23.16 (accessed 15 September 2014).

Vygotsky, Lev. 1978. Mind in society: The development of higher psychological processes. Cambridge, MA: Harvard University Press. 